\title{
HEALTH LITERACY, MEDIA EXPOSURE AND BEHAVIOR AMONG YOUNG ADULTS DURING THE COVID-19 PANDEMIC
}

\author{
Riza Hayati Ifroh, Tanti Asrianti \\ Public Health Faculty, Mulawarman University, Sempaja Sel., District. North Samarinda, Samarinda City, \\ East Kalimantan 75242, Indonesia
}

\begin{abstract}
Indonesia has published and released a new normal life, even though the COVID-19 rate continues to increase. The term of new normal life includes specific preventive behaviors as daily activity and supported skill by adequate health literacy of COVID-19. The purpose of this study was first to analyze the correlation of information media exposure to health literacy levels of COVID-19 and second to analyze the correlation between health literacy levels of COVID-19, exposure of information media to the adaptive behavior in COVID-19 prevention of young adult in East Kalimantan. The research design was a cross-sectional, quantitative study. The sampling technique used accidental sampling (254 young adults) data was taken by Google form. In data analysis to determine the correlation between gender to the level of health literacy of COVID-19 and new normal life used the Chi-square test. The analysis of age, exposure of mass and nonmass media to the level of health literacy of COVID-19 and, HL to new normal life behavior by using Spearman analysis test. The result statistics by gender $(p=0.748)$, age $(p=0.323)$, and health literacy level of COVID-19 ( $p=0.788)$ were not associated with the behavior of transmission of COVID-19 and prevention in new normal life. The variable of information exposure (by non-mass media and mass media) has a significant value associated with the variable of the behavior of new normal life ( $p$-value $<0.001$ ). The higher exposure of information media through mass and non-mass media have a correlation to increasing the health literacy level of COVID-19 and behavior to prevent the disease.
\end{abstract}

Keywords: Health literacy, Mass media, New normal life

\begin{abstract}
ABSTRAK
Indonesia telah mempublikasi dan merilis protokol adaptasi kebiasaan baru, walaupun angka konfirmasi COVID-19 masih mengalami peningkatan. Kehidupan normal baru meliputi pelaksanaan perilaku spesifik pencegahan COVID-19 sebagai bagian dari aktivitas sehari-hari dan didukung keterampilan oleh literasi kesehatan yang memadai. Tujuan penelitian ini adalah pertama menganalisis hubungan keterpaparan media informasi terhadap tingkat literasi kesehatan COVID-19 dan kedua untuk menganalisis hubungan antara tingkat literasi kesehatan COVID-19, keterpaparan media informasi terhadap perilaku adaptasi kebiasaan baru pencegahan COVID-19 kaum muda di Kalimantan Timur. Desain penelitian adalah kuantitatif dengan cross sectional. Menggunakan teknik pengambilan sampel accidental sampling sebanyak 254 kaum muda dan pengambilan data melalui Google form. Analisis data untuk menganalisis hubungan jenis kelamin terhadap tingkat literasi kesehatan COVID-19 dan kehidupan normal baru menggunakan uji Chi square. Analisis usia, keterpaparan media massa dan non-massa terhadap tingkat literasi kesehatan COVID-19 dan literasi kesehatan terhadap kehidupan normal baru menggunakan uji analisis Spearman. Hasil analisis statistik menunjukkan bahwa jenis kelamin $(p=0.748)$, umur $(p=0.323)$, dan tingkat literasi kesehatan COVID-19 $(p=0.788)$ tidak berhubungan dengan perilaku adaptasi kebiasaan baru. Pada variabel keterpaparan informasi media massa dan non massa memiliki hubungan secara statistik ( $p$-value $<0.001$ ) terhadap tingkat literasi kesehatan dan perilaku adaptasi kebiasaan baru. Pemaparan media informasi yang semakin tinggi melalui media massa dan non-massa dapat mempengaruhi tingkat literasi kaum muda tentang COVID-19 dan perilaku pencegahan penyakit ini di era adaptasi kebiasaan baru.
\end{abstract}

Keywords: Literasi kesehatan, media massa, adaptasi kebiasaan baru

Correspondece Address: Riza Hayati Ifroh, Public Health Faculty, Mulawarman University, Sempaja Sel., District. North Samarinda, .Samarinda City, East Kalimantan 75242, Indonesia, E-mail : rizahayatiifroh@gmail.com 


\section{Introduction}

The World Health Organization has issued a declaration regarding the SARS-CoV-2 outbreak or what is known as Corona Viruses Disease-2019 (COVID-19) as a public health emergency at the global level. ${ }^{1}$ The increase in cases of COVID-19 as a pandemic has increased making a lot of countries, including Indonesia perform protection and surveillance practices and the region in which human interaction with the mechanisms including social distance, physical distance, the regional quarantine or PSBB (large scale social limits) for areas that are considered to have an emergency status is also had determined. ${ }^{2}$

Based on WHO data (August 16, 2020) the accumulated number of positive COVID-19 confirmations globally is $24,299,923$, with a total number of new deaths $(5,985){ }^{3}$ Indonesia in the latest situation report on the development of COVID-19 by the Ministry of Health, as many as 165,887 cases confirmed positive with CFR $(4.3 \%){ }^{4}$

The determinants that affect the behavior pattern of preventing the transmission of COVID19 is the knowledge or level of public literacy in receiving and transferring correct information about this disease. ${ }^{5}$ Health literacy is the people's capacity to receive, understand, conclude, and apply information to make health decisions ,including healthy behavior and self-care activities. ${ }^{6}$ Decision making on the health of young people was influenced by ability in critical thinking and evaluate every health media literacy which received. ${ }^{7}$ Young people are considered a group that has a high level of mobilization in the community, this level of mobilization is a concern to reduce the rate of spread of COVID-19. ${ }^{8}$ Previous research has also explained that young people need to be empowered and improve their health literacy so that they can become a model for personal health education and more massive social change in preventing COVID-19. ${ }^{6,8}$

Based on previous research in level of knowledge regarding COVID-19 as many as 96.9\% of participants with high knowledge. ${ }^{9}$ In other studies were conducted to South Kalimantan society as many as $69.2 \%$ of the respondents were also in high knowledge level about COVID-19. ${ }^{10}$ The high level of knowledge and health literacy might based on the rate of information disseminated by young generation or adult through digital features. ${ }^{5,11}$ The digital media platform that are increasingly being used are online magazines, Tiktok applications, youtube, and other social messangers. ${ }^{7,12,13}$ Young adult means those who are 13-39 years old. ${ }^{14}$ Young people are considered as agents of change who encourage positive social change by utilizing digital media to disseminate appeals and information in dealing with new normal situations. ${ }^{15}$

East Kalimantan is one of the provinces in Indonesia has experienced an increase in new cases with a total number of confirmations of 3,723 (August 28, 2020). ${ }^{16}$ The early behavior of handling and preventing COVID-19 determines the success of prevention efforts at the community 
level of sustainable society at the stage adaptation of new normalcy to the pandemic. ${ }^{17}$ The term of new normal life includes the management of specific preventive behaviors for COVID-19 as part of daily activity ${ }^{18}$ The forms of behavior applied include washing hands often, using a mask when in outdoor activity, keep in distancing, avoid crowding, and improvement of individual quality of nutrition. ${ }^{19,20}$

Various researches have been conducted to analyze behavior and literacy level or knowledge about COVID-19, however specific content regarding exposure to information regarding mass and non-mass media and behavior of COVID-19 prevention in the new normal era, especially in groups of people youth, is still limited. More in-depth studies are needed to obtain valid and accurate statistical assumptions so as to provide comprehensive information to describe the level of health literacy of COVID-19, exposure to information media and a description of new adaptation behavior in new normal life era in youth groups. Based on these descriptions, the purpose of this study were first to analyze the correlation of information media exposure to health literacy levels of COVID19, second to analyze the correlation between health literacy levels of COVID-19, exposure of information media to the adaptive behavior in COVID-19 prevention of young adult in East Kalimantan.

\section{Method}

The design of this study was a cross-sectional quantitative study with a survey approach. The research was conducted from June to August 2020. The target group research was a young adult (17 - 33 years old) who had studied at the university level in East Kalimantan and agreed to be a participant of this study. The sampling technique used non probability sampling with accidental sampling. The number of participants as many as 254 , and data was taken by Google form application. The COVID-19 health literacy variable identifies the knowledge level of respondents regarding spread and symptoms and specific prevention behavior ${ }^{21}$ and how find and understand information about the corona virus ${ }^{22}$, the score of cut point adapted by Test of Functional Health Literacy in Adults' Questionnaire (TFHLAQ) ${ }^{6}$. As for categorization in the variable health literacy and behavior of new normal life using cut-point scores $(<60)$ for the inadequate or low, $(60-75)$ for the borderline or medium-level and (>75) for the adequate or high level ${ }^{6,22}$ The information media exposure variable identifies mass and non-mass media variations or information sources ${ }^{7,13,23}$. The indicators of new habitual adaptation behavior variable include 23 question items in an effort to prevent transmission (new normal life) COVID-19. ${ }^{17,18,24}$

There are two main points of the following bivariate analysis, 1) In data analysis to determine the correlation between gender to the level of health literacy of COVID-19 by using Chisquare test and analyze of age, exposure to mass and non-mass media to the level of health literacy of COVID-19 by using Spearman analysis test. 2) To determine the correlation between gender to 
new habitual adaptation behavior or new normal life by using Chi-square test, and to analyze the correlation between age, the health literacy level of COVID-19, mass and non-mass media exposure to new habitual adaptation behaviors also by using Spearman analysis test. Numerical data analysis used Spearman rank because the data were not normally distributed. This study has also passed the ethics commission by Faculty of Medicine, Mulawarman University with numbers 32/KEPK-FK/IX/2020.

\section{Results}

The correlation between the respondent characteristics by gender, exposure to mass and nonmass media information to the level of health literacy of COVID-19 and behavior in new normal life shows as follows. The categorization of variable health literacy and behavior of new normal life using cut-point scores $(<60)$ for the inadequate or low, $(60-75)$ for the borderline or mediumlevel and (>75) for the adequate or high level ${ }^{6,22}$

In this study, 254 participants aged 17-33 years were interviewed, $63.7 \%$ of participants were female, and $30.3 \%$ were male. In the classification of the health literacy rate of COVID-19, $64.9 \%$ of male had adequate literacy levels, and only $19.5 \%$ were adequate, while the female group had adequate health literacy rates with $45.2 \%$. It is known that the percentage of respondents at the level of health literacy of COVID-19 inadequate was 37.4\%, the borderline was $54.3 \%$, and inadequate was $8.3 \%$. Based on data about information sources through non-mass media, show that the highest proportion of information sources is obtained from parents or family (73.2\%) with an average value of 76.48 (SD 10.95). Peers $(67.3 \%)$ and health providers $(64.2 \%)$ were also involved in delivering information about COVID-19, while religious leaders only contributed (20.1\%).

Participants who received exposure to information sourced from the online conference (48.1\%) and celebrities act (48.1\%). The highest percentage of respondents received information from the internet (84.5\%), Instagram (83.7\%), and Whatsapp (73.3\%) through personal broadcasts or group activities. The following is a descriptive analysis of the variable health literacy of COVID-19 and behavior in new normal life. 
Table 1. Frequency distribution of characteristic respondents, information media exposure to the health literacy level of COVID-19 and behavior in new normal life

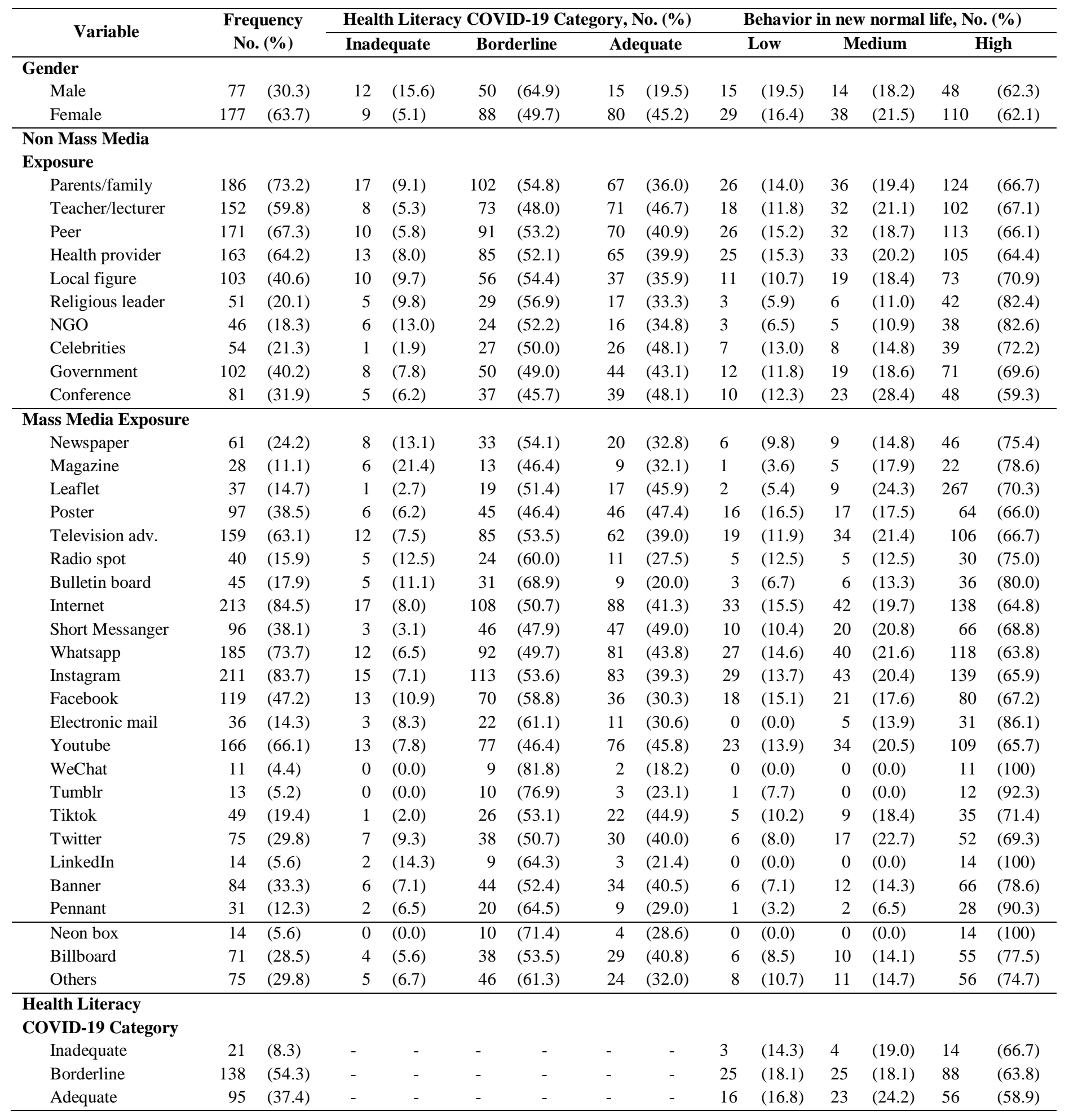


Based on the table 2 below, known that as many as $99.2 \%$ of young people get information about the symptoms of COVID-19 infection. Some aspects of the lack of understanding regarding efforts to encourage families to always use masks (22.8\%) and maintain distance (44.9\%). Respondents also did not understand cough etiquette (44.5\%) and detected the measurement of COVID-19 (31.9\%).

Table 2. Frequency distribution indicators of health literacy level of COVID-19

\begin{tabular}{lccc}
\hline \multicolumn{1}{c}{ Health Literacy of COVID-19 } & $\mathbf{n = 2 5 4}$ & $\mathbf{\%}$ & SD \\
\hline Find information about the coronavirus as a respiratory distress & 190 & 74.80 & 0.435 \\
Find information about coronavirus transmission & 147 & 57.87 & 0.495 \\
Find information about symptoms of coronavirus disease & 252 & 99.21 & 0.089 \\
Find information about transmission by droplets of infected persons & 254 & 100.0 & 0.000 \\
Find information about groups at risk of exposure to coronavirus & 164 & 64.57 & 0.479 \\
Understand the function of masks to prevent coronavirus & 229 & 90.16 & 0.298 \\
Understand how to use the masks as prevention & 251 & 98.82 & 0.108 \\
Understand viruses cling to and survive on objects & 229 & 90.16 & 0.298 \\
Understand the information about local transmission of coronavirus & 246 & 96.85 & 0.175 \\
Find information about smoking aggravates the infected level & 178 & 70.08 & 0.459 \\
Understand advice from family members or friend to physical distance & 114 & 44.88 & 0.498 \\
Understand in the media how to washing hand as prevention & 252 & 99.21 & 0.089 \\
Judge the family or friends to always using mask & 58 & 22.83 & 0.421 \\
Understand recommendations of authorities about mass disinfection & 154 & 60.63 & 0.490 \\
Understand how to increasing daily nutrition intake & 126 & 49.61 & 0.501 \\
Understand protective measures can apply to prevent infection & 81 & 31.89 & 0.467 \\
Judge what the ethics when coughing or sneezing & 113 & 44.49 & 0.498 \\
\hline Understand what to do after being outdoors & 253 & 99.61 & 0.063 \\
Understand how adequate rest can increases immunity & 251 & 98.82 & 0.108 \\
Use the information to decide health behavior prevention taken & 214 & 84.25 & 0.365 \\
\hline
\end{tabular}

Table 3 below shows an overview of the behavior to prevent the transmission of COVID 19 in the new normal life era. The most common behaviors were washing their hands more often (98.05\%), bring hand sanitizer $(89.37 \%)$, covering their mouths when coughing or sneezing by using their inner arms or elbows (92.91), and wearing masks (95.28\%). In the aspect of fulfilling nutrition was still quite low regarding the consumption of vegetables per meal (70.08\%) and a variety of fruit $(56.30 \%)$. It is known that as many as $(87.40 \%)$ of young people were realize that after being outside, they immediately change their clothes and take a shower, as many as $(61.81 \%)$ brought their own cutlery and $(60.24 \%)$ brought their own tumblers. 
Table 3. Frequency distribution indicators of behavior in new normal life by young adults

\begin{tabular}{lccc}
\hline \multicolumn{1}{c}{ Behavior in new normal life } & $\mathbf{n}=\mathbf{2 5 4}$ & $\mathbf{\%}$ & SD \\
\hline Hand wash often & 249 & 98.03 & 0.139 \\
Cough or sneeze in bent elbow, not hands & 236 & 92.91 & 0.257 \\
Avoid close contact with someone sick & 213 & 83.86 & 0.369 \\
Sleep period 7-8 hour each day & 196 & 77.17 & 0.421 \\
No smoking & 220 & 86.61 & 0.435 \\
Physical activity & 159 & 62.60 & 0.485 \\
Hand sanitizer & 227 & 89.37 & 0.309 \\
Using non cash payment & 174 & 68.50 & 0.465 \\
Avoid using public or online transportation & 214 & 84.25 & 0.365 \\
Consume vegetables per meal & 178 & 70.08 & 0.459 \\
Consume at least 3 variants fruit each day & 143 & 56.30 & 0.497 \\
Avoid the social crowd & 237 & 93.31 & 0.250 \\
Study or work from home & 231 & 90.94 & 0.288 \\
always keep social distance 2 meters or more & 211 & 83.07 & 0.376 \\
Consume vitamins & 199 & 78.35 & 0.411 \\
Use mask in outdoor area & 242 & 95.28 & 0.213 \\
Clean and disinfect frequent touched object & 189 & 74.41 & 0.437 \\
Looking for information of COVID-19 & 207 & 81.50 & 0.389 \\
Always bring own cutlery & 157 & 61.81 & 0.487 \\
Always bring own tumblers & 153 & 60.24 & 0.490 \\
Avoid touching eyes, nose and mouth & 210 & 82.68 & 0.379 \\
Drink eight glasses water per day & 165 & 64.96 & 0.477 \\
Take a shower immediately after travelling & 222 & 87.40 & 0.329 \\
\hline
\end{tabular}

In this study based on analysis in table 4 below, 254 participants aged 17-33 years and gander were statistically correlated to health literacy of COVID-19 $(P<0.001)$ whom younger respondents and female group had higher health literacy level. Based on data about information sources through non-mass media has significance value $(P=0.011)$, and the variable of mass media exposure had correlation with health literacy level of COVID-19 with significance value (P value 0.026 or $\mathrm{P}$ value $<0.05$ ).

Table 4. The correlation analysis of health literacy level of COVID-19, information media exposure and behavior in the new normal life of young adults

\begin{tabular}{llcc}
\hline \multicolumn{1}{c}{ Dependent Variable } & \multicolumn{1}{c}{ Independent Variable } & $\boldsymbol{P}$-value & Coefficient value \\
\hline \multirow{3}{*}{$\begin{array}{l}\text { Health literacy level } \\
\text { of COVID-19 }\end{array}$} & Gender & $<0.001$ & - \\
& Age & $<0.001$ & -0.242 \\
& Non mass media exposure & 0.011 & 0.160 \\
& Mass media exposure & 0.026 & 0.139 \\
\hline \multirow{3}{*}{ Behavior in new } & Gender & 0.748 & - \\
normal life & Age & 0.323 & 0.062 \\
& Non mass media exposure & $<0.001$ & 0.222 \\
& Mass media exposure & $<0.001$ & 0.267 \\
\hline
\end{tabular}


The statistical test analysis in the table above also shows that gender, age, and health literacy level of COVID-19 unaffected to the behavior of transmission of COVID-19 and prevention in new normal life, indicated by these three variables with $P$-value $>0.05$. The variable of information exposure to behavior of new normal life in non-mass media and mass media has a significant value ( $P$-value $<0.001)$, with the variable coefficient value of non-mass media information sources $(0.222)$ and mass media information sources $(0.267)$ which indicate the strength of low correlation. Based on descriptive data, media exposure through mass media has a higher intensity in increasing health literacy to young adult.

\section{Discussion}

In general, health literacy is a concept that describes the level of knowledge, motivation, analyzes and describes health information that is received for application in human life. ${ }^{22}$ The inequity in health literacy levels can result in the process of changing behavior being hampered. ${ }^{25}$ Efforts to increase health literacy and awareness to handling COVID-19 are urgently needed. All elements of government, society, educational institutions and other sectors need to focus on these emergency, especially in this generation. ${ }^{26,27}$ The generations is meaning by multiple perspectives, they typically refer to a group of person who born during the same time period with same situation today or COVID-19 experiences are assumed to have an impact on collective affection, norms value, or behaviors ${ }^{28}$. Young adults in East Kalimantan in general, based on these study shown that they were ini borderline level in health literacy of COVID-19. Based on this research result, more than some of the participants had a health literacy level for COVID-19 at the borderline level (2029 years old) were 54.6\% ( $P$-value $<0.001$ ), the level of acceptance of information quickly and effectively is accepted by youth groups ${ }^{29}$ because they have a level of curiosity and a long memory. ${ }^{30}$ The limitations that arise in this group were insensitive to analyzing and filtering the validity of information, ${ }^{5,730}$ which can help people identify reliable sources of information and investigate which information might be misleading 22 thus making health literacy skills important for young people to have. The result showed that $(64.2 \%)$ young adults received the information from health provider. The knowledge level of young people was also influenced by information conveyed through non-mass media or conveyed oral by the closest significant person, example family, peer group or people they trusted. ${ }^{31}$ It is therefore imperative that public health practitioners are aware of mass media coverage on emerging health threats such as COVID-19. ${ }^{31,32}$ Besides, health providers role, parents or family followed to campaign COVID-19 issue in their family circumstances $(73.2 \%)$, the one of parent's obligation is to remain and explain disease prevention such as personal hygiene, stay at home to their children when pandemic ${ }^{33}$. Information resources from non-mass media have correlation to the health literacy level of COVID-19 with ( $P$-value 0.011) $(P$-value $<0.05)$. 
The mass media, healthcare organization, community-based organizations, and other significant stakeholders should develop networking strategies and launch common platforms for disseminating authentic public health messages. ${ }^{5}$ It is in line with research results that mass media as the channel of information have statistics significantly with (P-value 0.026) to the increasing of health literacy level about COVID-19. The highest of adequate level in health literacy from mass media was a conventional poster and digital poster (mean: 76.34; SD: 11,67). The highest rate of exposure mass media to participants was the Instagram platform (83.7\%) and WhatsApp application broadcast and group communication activity (73.7\%) with a level of health literacy in borderline level both groups. The development of technology, especially devices or smartphones, is growing rapidly ${ }^{34,35}$ significant increase in its users in Indonesia from 15\% in 2014 to 51\% in 2017. This condition places Indonesia as the country with the highest growth of Internet users, more than five times the global average in 2016-2017. ${ }^{36}$ In a pandemic era, these situations can be an advantage and excellence in promoting health behavior ${ }^{31}$. The results of the study were also in accordance with previous research, which explains that the audio-visual social media of Facebook (47.2\%) and YouTube (66.1\%) may be more efficient for oral health promotion to adolescent when compared to a simple text-based medium such as Twitter (29.8\%) to increase health behavior of COVID-19 prevention. ${ }^{7}$

Indonesia has published and released a new normal life, even though the COVID-19 rate continues to increase. ${ }^{2,3}$ Social control of the spread COVID-19, be essential that public health officials know the groups were most heavily affected by the disease and that all individuals have accessibility to trusted guidance on how to protect themselves and their communities from infection. ${ }^{21}$ Based on the statistical analysis, it shows that gender, age, and health literacy level of COVID-19 unaffected to the behavior of transmission of COVID-19 and prevention in new normal life, indicated by these three variables with $P$-value $>0.05$. The variable of information exposure to the behavior of new normal life in non-mass media and mass media has a significant value (P-value $<0.001)$, with the variable coefficient value of non-mass media information sources $(0.222)$ and mass media information sources (0.267) which indicate the strength of low correlation.

This study explains that the level of health literacy about COVID-19 was not statistically related to new habitual adaptation behavior $(P$-value $=0.788$ ), this is in accordance with the results of other previous studies which state that the level of knowledge and health literacy is not the only determinant of behavior changes. ${ }^{17}$ The decision making to prevent transmission of COVID-197,38 was also determined by the aspect of personal autonomy in behaving and synthesizing health messages. ${ }^{39}$ It should be noted that health conditions of infection status or sick experiences can be an obstacle to preventive behavior for the spread of COVID-19, although the evidence of immunity after being infected with COVID-19 is inconclusive. ${ }^{21}$ The youth in East Kalimantan who participated in this study appear very literate to follow the COVID-19 prevention, and this is in line 
with the description of research that has been conducted on other groups of western European adolescents. $^{40}$

The aspect of adaptation behavior of adolescents in new normal life in East Kalimantan as many as $93.31 \%$ avoid the social crowd, this is higher than students of Syarif Hidayatullah Jakarta, which is only $55.9 \%$ have implemented physical distancing behavior. ${ }^{41}$ The behavior in new normal life that should be delivered by health providers by innovative mass media channel are washing their hands more often, covering their mouths when coughing or sneezing by using their inner arms or elbows, and wearing masks. ${ }^{8,17,42}$ The young adult group has to adapt behavior in the new normal era avoiding crowds and try to stay at home. ${ }^{20,33}$ In the aspect of fulfilling nutrition was still quite low regarding the consumption of vegetables and a variety of fruit in the daily menu. ${ }^{43}$ In all of aspect, new normal behavior of a young adult, achievable strategies for mass media campaigns and a significant person who delivered information from the last few epidemics should be identified and implemented. These messages should be culturally tailored and translated into several languages to increase outreach ${ }^{31}$. The information package must depend on the current situation and young adult interest and psychological factors, both in terms of belief, motivation, and encouragement to behave in preventing COVID-19 as well as participating in disseminating correct information about COVID-19.

\section{Conclusion}

In this study, the factors related to the health literacy level of COVID-19 are age, gender, exposure to information media through mass and non-mass media received during the COVID-19 pandemic. Besides, the exposure of health information from health providers, family, peers, and mass media or other social media had a statistical correlation to new normal life behavior of COVID-19 prevention. This study showed that the health literacy level of COVID-19 does not have a statistical correlation to new normal life behavior. The recommendation that given is continuously increase the exposure to information regarding efforts to prevent COVID-19 according to the needs and development of the case. The use of digital and non-digital mass media for communication is very much needed in increasing youth literacy about COVID-19 prevention. The use of media must be adjusted to the interests of young people such as whatsapp group, instagram, digital posters and youtube, equipped with language that understood easily. Although the level of literacy indirectly has a significant correlation with adapting behavior to new habits, the level of literacy remains one of the determining factors in the decision to behave more personal in.

\section{Acknowledgement}

We thank to all the participants who have contributed to be respondents in this research. 


\section{Funding}

This research was not funded by any institution or others.

\section{Conflict of Interest}

The authors declare that they have no conflict of interest.

\section{Reference}

1. Sardi, Sarwoprasodjo S, Lubis DP, Suharjito D. Kearifan Lokal: Sebuah Analisis Sosiologi Komunikasi di Manggarai Barat. Sodality J Sosiol Pedesaan. 2019;136-42.

2. Saleh A. Challenges and Opportunities for Community Empowerment Practices in Indonesia during the Covid-19 Pandemic through Strengthening the Role of Higher Education.

3. Report S. Coronavirus disease. 2020;August.

4. Kementerian Kesehatan RI (Kemenkes RI). Situasi Terkini Perkembangan. 2020.

5. Tasnim S, Hossain M, Mazumder H. Impact of Rumors and Misinformation on COVID-19 in Social Media. 2020;171-4.

6. Moeini B, Rostami-moez M, Besharati F, Faradmal J, Bashirian S. Adult Functional Health Literacy and its Related Factors : A Cross-Sectional Study. 2019;6(1):24-9.

7. Tse CKW, Hons B, Bridges SM, Appling MA, Tesol GC, Srinivasan P, et al. Social Media in Adolescent Health Literacy Education: A Pilot Study Corresponding Author : 4:1-8.

8. Oosterhoff B, Ph D, Palmer CA, Ph D, Wilson J, S M, et al. Adolescents ' Motivations to Engage in Social Distancing During the COVID-19 Pandemic: Associations With Mental and Social Health. J Adolesc Heal [Internet]. 2020;1-7. Available from: https://doi.org/10.1016/j.jadohealth.2020.05.004

9. Purnamasari I, Raharyani AE. Tingkat Pengetahuan dan Perilaku Masyarakat Kabupaten Wonosobo tentang COVID-19. J Ilm Kesehat. 2020;(Mei):33-42.

10. Wulandari A, Rahman F, Pujianti N, Sari AR, Laily N, Anggraini L, et al. Hubungan Karakteristik Individu dengan Pengetahuan tentang Pencegahan Coronavirus Disease 2019 pada Masyarakat di Kalimantan Selatan. J Kesehat Masy Indones. 2020;15(1):42-6.

11. Medicine T. The pandemic of social media panic travels faster than the COVID-19 outbreak. 2020;(March):1-2.

12. Ifroh RH, Ayubi D. Efektivitas Kombinasi Media Audiovisual Aku Bangga Aku Tahu Dan Diskusi Kelompok Dalam Upaya Meningkatkan Pengetahuan Remaja Tentang HIV-AIDS Effectiveness of Aku Bangga Aku Tahu Audiovisual Media and Group Discussion in 
Improving Teenagers ' Knowledge of. 2018;1(1):32-43.

13. Liu Q, Zheng Z, Zheng J, Chen Q, Liu G. Health Communication Through News Media During the Early Stage of the COVID-19 Outbreak in China: Digital Topic Modeling Approach Corresponding Author : 2020;22.

14. Horng W, Lee C, Chen C. Classification of Age Groups Based on Facial Features. 2015;(September 2001).

15. Pamungkas AH. The Role of Youth to Improve Community Literacy about COVID-19. J Pendidik Luar Sekol. 2020;8(1):6-9.

16. Dinas Kesehatan Provinsi Kalimantan Timur. Press Release 164 COVID-19 Kalimantan Timur. 2020.

17. Lee M, You M. Psychological and Behavioral Responses in South Korea During the Early Stages of Coronavirus Disease. 2020;

18. Hall, Grenita; Lavie, Carl J; Arena R. A tale of two pandemics: How will COVID-19 and global trends in physical inactivity and sedentary behavior affect one another? Prog Cardiovasc Dis. 2020;(January).

19. Satria A, Hasanah H. Penyuluhan Adaptasi Tatanan Kebiasaan Baru Desa Tangguh COVID-19. J Pengabdi Masy Anoa. 2019;3(1):107-22.

20. Cahapay MB. Rethinking Education in the New Normal Post-COVID-19 Era: A Curriculum Rethinking Education in the New Normal Post-COVID-19 Era: A Curriculum Studies Perspective. 2020;(August).

21. Alsan M, Stantcheva S, Yang D, Cutler D. Disparities in Coronavirus 2019 Reported Incidence, Knowledge , and Behavior Among US Adults. 2020;3(6):1-11.

22. Okan O, Bollweg TM, Berens E, Hurrelmann K, Bauer U, Schae D. Coronavirus-Related Health Literacy: A Cross-Sectional Study in Adults during the COVID-19 Infodemic in Germany. 2020;2.

23. Ejaz W, Ittefaq M. Data for understanding trust in varied information sources, use of news media , and perception of misinformation regarding COVID-19 in Pakistan. Data $\mathrm{Br}$ [Internet]. 2020;32:106091. Available from: https://doi.org/10.1016/j.dib.2020.106091

24. Kementerian Kesehatan RI (Kemenkes RI). Adaptasi Kebiasaan Baru. In: Poster Katalog.

25. Abel T, Mcqueen D. Letter to the Editor Critical health literacy and the COVID-19 crisis. $2020 ; 1-2$.

26. Nguyen HC, Nguyen MH, Do BN, Tran CQ. People with Suspected COVID-19 Symptoms Were More Likely Depressed and Had Lower Health-Related Quality of Life : The Potential Benefit of Health Literacy. 2020;1661(March).

27. Paakkari L, Okan O. Comment COVID-19: health literacy is an underestimated problem. Lancet Public Heal [Internet]. 2020;5(5):e249-50. Available from: 
http://dx.doi.org/10.1016/S2468-2667(20)30086-4

28. Rudolph CW, Zacher H. “ The COVID-19 Generation ”: A Cautionary Note. 2020;XX(Xx):1-7.

29. Darnton A. GSR Behaviour Change Knowledge Review Practical Guide: An overview of Practical Guide: An overview of behaviour change models and their uses. In 2008. p. 43.

30. Schieffer A, Lessem R. The Integral University: Holistic development of individuals, communities, organisations and societies. Springer. 2014;44(4):607-26.

31. Basch CH, Clarke G, Erwin ZM-, Mohlman J, Cosgrove A, Quinones N. ScienceDirect News coverage of the COVID-19 pandemic: Missed opportunities to promote health sustaining behaviors. Infect Dis Heal [Internet]. 2020;25(3):205-9. Available from: https://doi.org/10.1016/j.idh.2020.05.001

32. Harapan H, Itoh N, Yufika A, Winardi W, Keam S, Te H, et al. Journal of Infection and Public Health Coronavirus disease 2019 ( COVID-19 ): A literature review. J Infect Public Health. 2020;13(5):667-73.

33. Li W, Liao J, Li Q, Baskota M, Wang X, Tang Y, et al. Public health education for parents during the outbreak of COVID-19 : a rapid review. 2020;8(10).

34. Samaha M, Hawi NS. Relationships among Smartphone Addiction, Stress, Academic Performance, and Satisfaction with Life. Comput Human Behav. 2016;57:321-5.

35. Cha S, Seo B. Smartphone use and smartphone addiction in middle school students in Korea: Prevalence, social networking service, and game use. Health Psychology Open. 2018.

36. Pratama AR. Investigating Daily Mobile Device Use among University Students in Indonesia. IOP Conf Ser Mater Sci Eng. 2018;325(1).

37. Nugrahaeni DT. Pola Asuh Orang Tua pada Remaja yg Kecanduan Bermain Game Online. Vol. 4, Fakultas Psikologi Universitas Muhammadiyah Malang. 2017.

38. Garcia AMU. Social Media for Health Promotion \& Education. Internist Medical Oncologist; 2018 p. 1-65.

39. Lupton D. Critical perspectives on digital health technologies. Sociol Compass. 2014;8(12):1344-59.

40. Riiser K, Helseth S, Haraldstad K, Torbjørnsen A, Richardsen KR. Adolescents' health literacy, health protective measures, and health-related quality of life during the Covid-19 pandemic. PLoS One. 2020;15(8 august):1-13.

41. Syadidurrahmah F, Muntahaya F, Islamiyah SZ, Fitriani TA. Perilaku physical distancing mahasiswa UIN Syarif Hidayatullah Jakarta pada masa pandemi covid-19. J Perilaku dan Promosi Kesehat. 2020;2(1):29-37.

42. Prayaga RB, Prayaga RS. Mobile Fotonovelas Within a Text Message Outreach: An 
Innovative Tool to Build Health Literacy and Influence Behaviors in Response to the COVID-19 Pandemic Corresponding Author : 2020;8:1-8.

43. Trends D, Carrasco-mar F, Paternina-sierra K, Rodriguez-meza JE, Visioli F, Alberto D. Covid-19 Confinement and Changes of Adolescent's Dietary Trends in Italy, Spain, Chile, Colombia and Brazil. 2020; 